Dhupelia-Mesthrie, U. (2016). Betwixt the oceans: The Chief Immigration Officer in Cape Town, Clarence Wilfred Cousins (1905-1915).

Journal of Southern African Studies, 42(3): 463-481.

\title{
Betwixt the oceans: The Chief Immigration Officer in Cape Town, Clarence Wilfred Cousins (1905-1915)
}

\author{
Uma Dhupelia-Mesthrie
}

Drawing on the personal and official papers of an immigration officer, this article highlights his personality, social life, and the quotidian aspects of his work at the port. By placing the officer at the centre, instead of the usual tendency in South African historiography to focus on ethnic immigration histories, one secures broader insights into the administration of policy, such as the writing test (an exclusionary mechanism) and repatriation, which are often associated with state policies against Indians. While the article draws on examples of arrivals at the port from both the Atlantic and Indian Oceans, arguing against a focus on only Indian Ocean traffic, it emphasises how arrivals from India played a role in shaping the immigration bureaucracy. While scholars have recently begun to see Cape Town as an important Indian Ocean port, this article points to settler society's unease with what sea traffic from Bombay and Durban might bring and how Cape Town sought to establish a disconnect with the East.

\section{Introduction}

Vishnu Datt Sharma, who began his 40-year career in the Indian civil service as a magistrate in Kota in Rajasthan, India, in the 1930s, quotes an Urdu couplet written by the poet Akbar Ilahabadi:

Kya Kahen Agyar Kya Kare Numyan Kar Gaye B.A. Kiye, Naukar Hue, Pension Mili Aur Mar Gaye

(What is there to relate about the life of a civil servant, whatever he did could be summed up in a line - he was born, he graduated, he got employed, earned his pension and died.) ${ }^{1}$

Despite other self-deprecating remarks, he none the less documented a career traversing British rule and independent India. There exist many such memoirs of Indian civil servants who thought their daily work as magistrates, district collectors or secretaries in various government departments worth recording. Prakash Krishen's A Bureaucrat's Diary is significant in its attempts to lift 'the enigmatic veils of bureaucracy'. He is anxious to stress that 'a bureaucrat is not "wooden" as he has sometimes been made out to be. He is a human like other people, with feelings and emotions, with his good points and weaknesses'.2

\footnotetext{
${ }^{1}$ V.D. Sharma, Through Two Systems: Encounters and Experiences of an I.A.S. Officer (New Delhi, Associated Publishing House, 1982), p. 138.

${ }^{2}$ P. Krishen, A Bureaucrat's Diary (New Delhi, Vikas Publishing House, 1977), pp. vii, x.
} 
Such published accounts by civil servants in South Africa are rare, and the few that do exist emanate from those charged with administering the African population; they sought to educate readers about the 'native'. ${ }^{3}$ Scholars of South Africa have generally paid scant attention to the lives of civil servants. 4 This is not to say that there has been neglect of bureaucracies. Much of this work has been concerned with departments administering the African population in the 2oth century, though there has been some, but not enough, attention to the Group Areas Board. Through these, one gains glimpses of the men behind the desks.5 Cynthia Kros provides one of the few detailed profiles of W.W.M. Eiselen and his career as Chief Inspector of Native Education in the 1930 and 1940 s before moving on to his work as chair of the commission on Bantu education. However, Kros consciously avoided a biographical project, deeming Eiselen's life bland and banal'. 6

There is a growing new interest in the immigration bureaucracies in Natal and Pretoria, and there have been some attempts to understand individual immigration officials, though these have been hampered by the lack of private papers.7 There is also a renewed focus on other officers, such as the Protector of Indian Immigrants in Durban, who oversaw the arrival of freed slaves and indentured labourers and their subsequent allocation to employers. ${ }^{8}$ My work on Clarence Wilfred Cousins shifts attention to the port of Cape Town, where Cousins served as an immigration officer in the Cape Colony and, later, Cape Province, between 1905 and 1915. His life provides an opportunity to understand the private and public world of the immigration officer. This article argues that such a focus on one who was charged with implementing policy provides a more complete understanding of policy, laws and bureaucratic workings. As Philip Selth has argued, 'public servants provide the sinews and

\footnotetext{
${ }^{3}$ See J. Peires, 'Nostalgia and the Native Commissioners: A Hundred Years in the Old Transkei', Kronos, 35 (2009), pp. 242-7, for a review of the memoirs of magistrates W.C. Scully and Frank Brownlee and the more contemporary account by Dial Ndimi, a magistrate in the Transkei.

${ }^{4}$ An exception would be the career of Theophilus Shepstone (see J. Guy, Theophilus Shepstone and the Forging of Natal:African Autonomy and Settler Colonialism in the Making of Traditional Authority (Pietermartizburg, University of Kwa-Zulu Natal Press, 2013), but he is hardly representative of the middle layer administrators of policy.

5 See D. Posel, The Making of Apartheid 1948-1961: Conflict and Compromise (Oxford, Clarendon Press, 1991); K. Breckenridge, 'Verwoerd's Bureau of Proof: Total Information in the Making of Apartheid', History Workshop Journal, 59 (2005), pp. 83-106; I. Evans, Bureaucracy and Race: Native Administration in South Africa (Berkeley, University of California Press, 1997); S. Dubow, 'Holding "A Just Balance Between White and Black": the Native Affairs Department in South Africa c.1920-1933', Journal of Southern African Studies, 12, 2 (1986), pp. 217-39; D. Posel, 'Whiteness and Power in the South African Civil Service: Paradoxes of the Apartheid State', Journal of Southern African Studies, 25, 1 (March 1999), pp. 99-119. For the Group Areas Act, see U.S. [Dhupelia-]Mesthrie, 'Tinkering and Tampering: A Decade of the Group Areas Act (1950 to 1960)', South African Historical Journal, 28 (1993), pp. 177-202; U.S.[Dhupelia-]Mesthrie, "No Place in the World to Go To" - Control by Permit: The First Phase of the Group Areas Act in Cape Town in the 1950s', in E. van Heyningen (ed.), Studies in the History of Cape Town, Vol. 7 (University of Cape Town, 1994), pp. 184-207. For a focus on the early years of the 20th century and the administrative controls over African labour, see K. Breckenridge, 'Lord Milner's Registry: The Origins of South African Exceptionalism', unpublished seminar paper, University of KwaZulu Natal, Durban, 2004, available at www.kznhass-history.net/files/seminars/Breckenridge2004.pdf, retrieved 16 March 2016.

${ }^{6}$ C. Kros, The Seeds of Separate Development: Origins of Bantu Education (Pretoria, Unisa Press, 2010), p. xiv.

7 See A. MacDonald, 'Strangers in a Strange Land: Undesirables and Border-Controls in Colonial Durban, 1897-c.1910, MA dissertation, University of Kwa-Zulu Natal, 2007, and his more ambitious work, 'Colonial Trespassers in the Making of South Africa's International Borders, 1900 to c. 1950', PhD thesis, University of Cambridge, 2012; J. Klaaren, 'Migrating to Citizenship: Mobility, Law, and Nationality in South Africa, 1897-1937', PhD thesis, Yale University, 2004; J. Hyslop, 'Oceanic Mobility and SettlerColonial Power: Policing the Global Maritime Labour Force in Durban Harbour c.1890-1910', Journal of Transport History, 36, 2 (2015), pp. 248-67.

${ }^{8}$ See the article by Preben Kaarsholm in this issue. One of the older studies of the Protector is that by P. Warhurst, 'Obstructing the Protector (of Indian Immigrants)', Journal of Natal and Zulu History, 7 (1984), pp. 31-40, but this is more about the Protector's role as intermediary between employers and employees.
} 
muscle that make the body politic work'. A focus on their careers provides an entry into 'administrative routine'.9 Civil servants can also thwart policy, as Amit and Kriger have recently argued. ${ }^{10}$

Cousins, left behind not only an extensive official archive of his decision-making and administration, ${ }^{11}$ but also a collection of diaries, family letters and public lectures. ${ }^{12}$ There also exists a small memoir, self-published towards the end of his life.13 Cousins developed the practice of keeping a journal from an early age. However, from simply listing activities of the day, his diaries grew in scale, and those, particularly after Union, reveal a more concerted effort at self-documentation. The weekly diary in these later years was posted to family in England, circulated, and returned to Cousins. This practice signalled a belief in keeping a record for the future, apart from its significance back home. He observed: '[a]s very flattering use is made of it at home, I feel in duty bound to keep it up if possible'. ${ }^{14}$ Through these, we gain an insight into not only the career of a civil servant but also the personality of the man and his social life. Such an integrated attempt to understand what kind of man the immigration officer was marks a significant departure from the literature that tends to focus on the official work of such officials without understanding their lives outside work. It provides an opportunity to respond to the issue raised by Julie Evans: 'in terms of the relationship between biography and history... how the idiosyncratic characteristics of one individual interacted with the more general economic, social and political interests that he was employed to pursue'. ${ }^{15}$ Did Cousins place an 'individual stamp' on the bureaucracy he headed? ${ }^{16}$ What did his own work mean to him?

Cousins' career as immigration officer is linked to the passage of the Immigration Act 47 of 1902 and Act 30 of 1906 of the Cape Colony, as well as the Immigration Regulation Act of 1913 of the Union of South Africa, the provisions of which he had to implement. This article argues that by shifting the focus of immigration histories from the places of origin or the ethnicities of immigrants to the port of arrival and the work of the officer, new insights are to be gained into the workings of these laws. This is demonstrated in two instances - one in terms of the writing test for entry and, secondly, in our understandings of repatriation. The 1902 and 1906 Acts have been accorded some significance in accounts of Indian Ocean crossings. It has been argued that the imposition of a writing test in a European language, and the provision that new immigrants must have $£ 20$ on their person on arrival at the port, effectively closed off

\footnotetext{
${ }_{9}^{9}$ P.A. Selth, 'Political Biographies and Administrative Memoirs: Some Concluding Comments', in T. Arklay, J. Nethercote and J. Wanna (eds), Australian Political Lives: Chronicling Political Careers and Administrative Histories (Canberra, ANU E Press, 2006), p. 111. For a focus on biography, history and careers that crossed several imperial sites, see D. Lambert and A. Lester (eds), Colonial Lives Across the British Empire: Imperial Careering in the Long Nineteenth Century (Cambridge, Cambridge University Press, 2006).

${ }^{10}$ See R. Amit and N. Kriger, 'Making Migrants "Ill-legible": The Policies and Practices of Documentation in Post-Apartheid South Africa', Kronos, 40 (2014), pp. 269-90.

11 These are to be found in the Western Cape Archives and Records Services (Cape Town) and are separated into three series: Principal Immigration Officer (PIO), for whites; Interior Regional Services (IRC 1/1), for Indians; IRC 1/2, for Chinese.

${ }^{12}$ See University of Cape Town Libraries (hereafter UCT), Manuscript Collection, Clarence Wilfred Cousins Papers BC 1154.

${ }^{13}$ UCT, Cousins Papers BC 1154, E4, Reflections of a Nineteenth Century Immigrant 1896-1950 (Tzaneen, self-published, 1950).

${ }^{14}$ UCT, Cousins Papers BC 1154, A4.1.3, Diary for 1913, 19 March 1913.

15 J. Evans, 'Biography and Global History: Reflections on Examining Colonial Governance Through the Life of Edward Eyre', in D. Deacon, P. Russell and A. Woollacott (eds), Transnational Ties: Australian Lives in the World (Canberra, ANU E Press, 2008 ), p. 25.

16 J. Nethercote, 'Anonymous in Life, Anonymous in Death: Memoirs and Biographies of Administrators', in Arklay, Nethercote and Wanna (eds), Australian Political Lives, p. 89.
} 
fresh immigration from India, except for children and wives of resident Indians. ${ }^{17}$ Chanock has argued quite compellingly that 'South African thinking and institutions did not develop in isolation'18 - in the case of the writing test to exclude immigrants, there is the influence of the American test to exclude African American voters in the south. ${ }^{19}$ Scholars have equally been at pains to demonstrate how this test for immigration purposes spread among Indian Ocean ports, with Natal having first enacted it in 1897. Australian legislators drew on Durban's example to restrict entry at their ports in 1898 and 1901. The Cape Colony followed suit in 1902, when there was public hysteria at ships arriving at the Cape ports bearing large numbers of Indian passengers unable to land in Durban. While provision was made to exclude the illiterate European poor from the language and monetary requirements, provided they had work contracts, there were no such concessions made for those from the East. ${ }^{20}$ Jeremy Martens has observed that this 'shared history of immigration restriction ... bound together settler society on both sides of the Indian Ocean'. ${ }^{21}$ In 1903, Natal, inspired by Australian practice, altered its writing test from a request to complete a form to a dictation test. ${ }^{22}$

The writing test has been accorded only a small place in the history of Jewish immigration to the Cape. Many Jewish immigrants, escaping the perils of Russian rule, came to the Cape via Southampton and travelled down Africa's Atlantic coastline. Scholars have noted the role of the lawyer Morris Alexander in successfully ensuring that Yiddish was recognised as a European language in the 1906 Act. The writing test then loses relevance in the history of Jewish immigration. ${ }^{23}$ This article argues that the writing test had a longer relevance, and needs to be understood beyond its Indian Ocean context. It seeks to break the rigid lines of separation between studies of immigration from the East and immigration from the West (a characteristic of South African historiography). The immigration officer's work encompassed arrivals from both the Atlantic and Indian Ocean.

Repatriation has very emotional meanings in the history of Indian South Africans; there were many coercive schemes to return them to India. Repatriation originally applied to indentured workers in Natal who could avail themselves of a free return passage to India on completion of their contracts. After 1914, however, any Indian in South Africa could take advantage of repatriation schemes that provided bonuses and a free passage to India on surrender of

\footnotetext{
${ }^{17}$ U. Dhupelia-Mesthrie, 'The Passenger Indian as Worker: Indian Immigrants in Cape Town in the Early Twentieth Century', African Studies, 68,1 (April 2009), pp. 118-19.

${ }^{18}$ M. Chanock, 'Criminological Science and the Criminal Law on the Colonial Periphery: Perception, Fantasy, and Realities in South Africa, 1900-1930', Law and Social Inquiry, 20, 4 (1995), p. 918.

19 See M. Lake, 'From Mississippi to Melbourne via Natal: The Invention of the Literacy Test as a Technology of Exclusion', in A. Curthoys and M. Lake (eds), Connected Worlds: History in Transnational Perspective (Canberra, ANU E-Press, 2005), pp. 209-20.

${ }^{20}$ Dhupelia-Mesthrie, 'The Passenger Indian as Worker', pp. 118-19.

21 J. Martens, 'A Transnational History of Immigration Restriction: Natal and New Zealand, 1897-99', Journal of Imperial and Commonwealth History, 34, 3 (2006), p. 325; also A. McKeown, Melancholy Order: Asian Migration and the Globalisation of Borders (New York, Columbia University Press, 2008), pp. 193-7.

${ }^{22}$ See McKeown, Melancholy Order, pp. 195-7; S. Bhana and J.B. Brain, Setting Down Roots: Indian Migrants in South Africa, 18601911 (Johannesburg, Witwatersrand University Press, 1990), p. 131.

${ }^{23}$ See R. Mendelsohn and M. Shain, The Jews in South Africa: An illustrated History (Johannesburg and Cape Town, Jonathan Ball, 2008), pp. 47, 57, 60 .
} 
South African domicile. ${ }^{24}$ This article suggests that through a study of Cousins' work we are able to see that repatriation can be broadened to encompass other unwanted groups.

At the beginning of the 20th century, and with the South African War (1899-1902) drawing to a conclusion, a new order was in the making, led by the new British rulers of the former Boer Republics. There was a preoccupation with defining and excluding the undesirable elements of society - criminals, but also 'destitute foreigners, especially East European and Russian Jews'. Martial law enabled the deportation of many Russians, Greeks, Italians, Austrians and Germans, and a new law in 1902 sought, as Diana Cammack argues, 'to protect the new Colonies against the influx of persons socially, and in some cases, politically undesirable'. ${ }^{25}$ This preoccupation with the undesirable is echoed in the Cape Colony's Immigration Acts of 1902 and 1906, which excluded not only those from the East (by its prescription of a European writing test), the illiterate and the financially unsound, but also prostitutes, those with criminal records and those with mental illnesses. The Chinese Exclusion Act of 1904 prohibited the entry of an entire group, irrespective of their economic calling and status.

After Union, the 1913 Act provided that a prohibited immigrant could be 'any person or class of persons deemed by the Minister on economic grounds or on account of standard or habits of life to be unsuited to the requirements of the Union or any particular province thereof'. Under this provision, Asians were specifically declared a prohibited group. ${ }^{26}$ As Perbedy and Vinson have shown, 'non-whites' or 'coloured persons' were also excluded, though not Africans under labour contracts. The Act additionally prohibited 'any idiot', 'epileptics', the 'insane and mentally deficient', the 'physically weak' and the disabled. Those with 'contagious and loathsome' diseases, including tuberculosis in its active phase, were also excluded. As with the Cape's immigration laws, the 1913 Act listed for exclusion pimps and prostitutes, those with criminal records and those who would become a burden to the state. ${ }^{27}$

The exclusion of the mentally weak reflected many decades of thought among the ruling classes in Britain and the South African colonies about 'degeneracy and feeblemindedness'. As Chanock argues, 'the categories of moral imbecile, moral insanity, degeneracy and feeblemindedness ... became a basic part of criminological thought'. ${ }^{28}$ Destitute and idle whites who would create social problems and end up being a liability to the state were also as unwanted, as were those from the East. Cape officials, as Sarah Duff has shown, had long been concerned to address the question of the idleness of white youth, to ensure a more productive society. ${ }^{29}$ Keeping out those unable to work may be seen as a logical outcome of such debates - the nation wanted healthy, able bodies or those with means.

\footnotetext{
${ }^{24}$ See U.S. [Dhupelia-]Mesthrie, 'Reducing the Indian Population to a "Manageable Compass": A Study of the South African Assisted Emigration Scheme of 1927', Natalia, 15 (1985), pp. 36-56.

25 D. Cammack, The Rand at War 1899-1902: The Witwatersrand and the Anglo-Boer War (London, James Currey, 1990), pp. 158, 198.

${ }^{26}$ P.S. Joshi, The Tyranny of Colour: A Study of the Indian Problem in South Africa (Durban, self- published, 1942$)$, p. 76.

${ }^{27}$ See S. Perbedy, Selecting Immigrants: National Identity and South Africa's Immigration Policies, 1910-2008 (Johannesburg, Wits University Press, 2009), pp. 52-3; for the exclusion of African Americans, see R.T. Vinson, The Americans Are Coming: Dreams of African American Liberation in Segregationist South Africa (Athens, Ohio University Press, 2012), pp. 8, $27-8$.

${ }^{28}$ Chanock, 'Criminological Science', pp. 915-16.

${ }^{29}$ S.E. Duff, 'Saving the Child to Save the Nation: Poverty, Whiteness and Childhood in the Cape Colony', c.1870-1895', Journal of Southern African Studies, 37, 2 (2011), pp. 229-45.
} 
The work of the immigration officer encompassed keeping out the variety of undesirables specified, and through this lens we have a broader horizon than the view through the lens of ethnic immigration histories.

Ships called at Cape Town, sailing across and along the Atlantic coastline of Africa, and similarly there were Indian Ocean crossings. The Union Castle Mail Steamship Company bore passengers from Southampton, England via Madeira, and the Deutsch Ost-Afrika Linie sailing from Hamburg brought passengers from Bombay, with stops at the eastern and southeastern African ports, to Cape Town. Cousins' work history was thus extensive, involving passengers from most parts of the world. This article also argues that the arrivals at the Cape ports from India (of returning Indians or new arrivals such as minors and wives of residents Indians) played a significant role in shaping the work of the immigration bureaucracy, and determined how this Chief Immigration Officer's career was ultimately assessed.

\section{The Journey to the Civil Service}

Clarence Wilfred Cousins was born in 1872 at Antananarivo on the island of Madagascar . His father, Reverend William Cousins, originally hailing from Abingdon in England, had come to Antananarivo 10 years previously as a missionary of the London Missionary Society. In 1864, his English-born wife, Mary Williams, joined him. Mary gave birth to four sons (the eldest of whom died as an infant), of whom Wilfred, as he was called, was the fourth. Three daughters followed between 1874 and 1882. Except for a return to England between 1876 and 1878, Mary Cousins and her children remained with William until 1884, when they returned permanently to England. William stayed behind until the late 1890 os to continue with his work of translating the Bible into Malagasy and to carry out his mission work in the District of Ambohipotsy. 30 How significant were these Madagascar days in the life of Wilfred Cousins, given that he spent at least 10 formative years here? We know that the children became fluent in Malagasy, and they possessed a hymn book which their father had translated in Malagasy. The family had a bungalow in Antananarivo, their nanny was a Malagasy woman, their friends included English and Malagasy children, and they loved riding donkeys. ${ }^{31}$ For all the influences of the outside world, the Cousins' household in Madagascar was a very 'Christian English home'. A family member reflects:

the more severe affection of Victorian parents contrived to keep that remote household a pattern of a Christian English home. The children were not permitted to run wild. Each of them must learn to read the Bible aloud by the age of six, naughtiness was promptly repressed. Little tea parties and Christian dinners, with a few other British residents, were

\footnotetext{
${ }^{30}$ He returned to England in 1888 but left again in 1890, and would come back permanently to England only in 1899 . This family history is drawn from the family tree of William George Cousins obtained from freepages. family.rootsweb.ancestry.com (thanks to Andrew MacDonald for alerting me to this source). See additionally the 'Biography of William Edward Cousins', undated, School of Oriental and African Studies Library, London (hereafter SOAS), Hardyman Papers, pp ms63 j.t., Box 52, File 54.

${ }^{31}$ SOAS, Constance Cousins Papers, Box 1 Ms 380325/01/5, letters from Mabel to William Cousins, 11 February 1886,17 June 1886, and letters from Ada to William Cousins, 2 May and 11 October 1886; MS 380325/1, 'The Life and Travels of the late Dr E.C. Cousins', undated manuscript, Foreword by J.E. Cousins, pp. 2-5.
} 
conducted on the same formal lines as in Victorian England.... The children never saw Madagascar again, but the pattern of missionary life remained with them. $3^{2}$

The diaries and letters of Wilfred support the above perception but provide no clues as to what being on that island meant in his life. The only reference to be found is in Cousins' critique of D.F. Malan's policy towards Africans in the 1950s. Penned in the last years of his life, but in the early years of apartheid, Cousins referred to his whiteness but noted that he 'spent his boyhood days amongst brown and black people (not in Africa)'. He also referred to his last two decades living on a farm in Tzaneen with thousands of African neighbours in four nearby African reserves. 33 There is little indication that growing up with 'brown and black people' had any significance in his work as immigration officer. His English roots and the later influence of white settler society in Cape Town were of greater salience. 34

Once back in England, the family settled in Oxford, and Wilfred Cousins completed his matriculation at Oxford High School. He then went on to secure a BA in modern history from Oxford University. Several of his referees noted that his achievements at Oxford were marred by personal difficulties and that, in the last two years of study, he had to secure work as a teacher. 35 These could allude to his mother's illness and the need to support the household in his father's absence. Mary Cousins died in 1894, and, after holding several teaching positions, Wilfred began to look for a position in Cape Town.

He explained his decision to come to Cape Town as due to 'dissatisfaction with one's prospects in England, an interest aroused in South Africa, a readiness for adventure'. ${ }^{36} \mathrm{He}$ had come to Cape Town twice previously - in 1875 and 1884 - no doubt on the family's return journey from Madagascar to England. That the Cousins family had friends and contacts in Cape Town who could help to secure him a position may have played a role. Moving out of England was not an unusual occurrence for English families in this age of empire. All but of one of his siblings would, in fact, leave England to go to other places, such as Malaya, Borneo and India. Being in the colonies provided some interest and even status to the family left in England. As Hilda Murray, the sister of Wilfrid Murray, a friend of Cousins who followed him to the Cape a year later, wrote to her brother: 'I think our acquaintances find you an awfully safe topic. They always ask after "your brother in Africa", and discuss the Cape generally. We get quite a reflected glory from your being there'.37

Cousins' referees included Reverend James Murray (Wilfrid Murray's father), who headed the Oxford English Dictionary project; G.M. Richardson, the MA tutor and lecturer at Oriel and Pembroke Colleges, under whom he had read history; and principals at the schools he

\footnotetext{
32 SOAS, Constance Cousins Papers, MS 380325/1, 'Life and Travels', p. 5.

${ }^{33}$ UCT, Cousins Papers, BC 1154, H4, 'Dr Malan's Policy for South Africa’s Mixed Population', undated.

${ }^{34}$ I explore this further in my paper 'The Social World of Clarence Wilfred Cousins, Chief Immigration Officer in Cape Town, 19051915', paper presented at conference 'The Private Lives of Empire: Intimate Histories of the Settler Colony, 1800-Present', University of Sydney, Australia, 16-17 April 2015.

${ }^{35}$ Cousins left Oxford without attaining the MA, but acquired MA certification in later years, in accordance with the university policy of issuing such certificates.

${ }^{36}$ UCT, Cousins Papers, BC 1154, E4, Cousins, Reflections of a Nineteenth Century Immigrant, p. 6.

${ }^{37}$ UCT, Murray Family Papers, BC 1290, B5, Hilda to Wilf, 17 December 1897.
} 
taught at. They pointed to him being 'thoroughly painstaking and conscientious', possessing a 'gentlemanly character' and having the 'power of study'. Cousins' teaching repertoire included history, mathematics, English and music. 38 His intention, when he set sail from Southampton in August 1896, was to secure a teaching position.

A day after arriving in Cape Town on 6 September, Cousins met Dr James Cameron, the retired Registrar of the University of Cape of Good Hope, who was also, like the Cousins family, a Congregationalist. His father had also been a missionary in Madagascar in a much earlier period. Within 24 days of being in Cape Town, Wilfred began employment as a clerk in the Colonial Secretary's office. 39 He explains why, despite having two teaching offers, he chose the civil service: '[i]t is shameful to admit that the deciding factor, noting that salaries in two cases were paid quarterly and in the Civil Service monthly, was the light weight of the ten sovereigns in the purse'. ${ }^{40}$ He supplemented his salary by offering music lessons. ${ }^{41}$ While he hoped later to secure the post of assistant to the registrar at the University of Cape of Good Hope, this plan did not materialise ${ }^{42}$ and, instead, thus began Cousins' long association with the Cape and, later, Union civil service.

Cousins married Ethelwyn Murray, daughter of James Murray and sister of Wilfrid Murray, when she joined him in Cape Town in 1900 after several years of a long-distance romance. Both Wilfrid Murray and Wilfred Cousins and their spouses played an important role in the Sea Point Congregational Church, with which James Cameron had a long association. Diary entries reflect how Wednesday evenings and Sundays were preoccupied with church events and services. Cousins taught a Bible class and was also the choir's organist. He followed his father in his membership of the Christian Endeavour Society, started by a congregationalist in America in 1881, which spread across the world. In Cape Town, it was already well established by the time Cousins arrived. The society brought together Christians to promote their service to Christ and, in particular, sought to influence youth. 43

After several years as a clerk in the Colonial Secretary's office, Cousins was appointed a Deputy Inspector of Prisons in 1901, a post which involved travelling across the colony conducting prison inspections. When he left this position in 1905 to become a principal clerk and officer in charge of immigration and labour in the local government and health branch of the Colonial Secretary's office, his superior praised him: '[n]ot only were you thoroughly conversant with all the details of prison management, but your enforcement of discipline was beyond praise, and your manner of dealing with recalcitrant magistrates gave me keenest

\footnotetext{
${ }^{38}$ UCT, Cousins Papers, BC 1154, A2, references from James Murray, undated; Thomas Laing, 27 June 1896, G.N Richardson, 8 May and 15 June 1896.

${ }^{39}$ UCT, Cousins Papers, BC 1154, A4.2.1, Diary of 1896, entries 6 and 30 September.

${ }^{40}$ UCT, Cousins Papers, BC 1154, E4, Reflections of a Nineteenth Century Immigrant, p.7.

${ }^{41}$ UCT, Cousins Papers, BC 1154, A4.1.1, Diary for 1898, 28 February, 3 March.

${ }^{42}$ Ibid., 14, 15, 16, 18 February.

${ }^{43}$ For a history of the Christian Endeavour Movement, see www.worldsceunion.org/history (retrieved 9 March 2016), in particular the sections on its spread in South Africa. The first society in the Cape was started in Wellington in 1887. Society members took the Christian Endeavour pledge, 'Trusting in the Lord Jesus Christ for strength, I promise Him that I will strive to do whatever He would like to have me do'.
} 
satisfaction'.44 Cousins' successor in the Cape Immigration Department in 1916, E. Brande, came with experience as a commander at Robben Island.

The administration of the Immigration Act of 1902, originally under the medical officer of health, had since 1904 been administered by a designated officer in charge of immigration and labour. Cousins was the second incumbent. 45 Under the 1906 Immigration Act, Cousins secured the official title of Chief Immigration Officer of the Cape Colony. He was based in Cape Town, as this was the most significant of the Cape ports, attracting most of the passenger traffic, but all the Cape ports were his responsibility. For a time in 1908, while holding this post, he served in a temporary capacity as superintendent of the East London Convict Station. In 1912, he had a six-month stint in Durban as Principal Immigration Officer during the absence of Harry Smith. ${ }^{46}$ By the end of his service in the Cape Immigration Department, the Cape Town office had about 12 members of staff. 47 Cousins hoped that Union would lead to a restructuring of the Immigration Departments of the Cape and Natal, which would result in his appointment as the Union of South Africa's Principal Immigration Officer. 48 This amalgamation did not happen, but Cousins retained control of the Cape ports, his titles now being Principal Immigration Officer and Chief Clerk in Charge. He retained this until mid 1915, when he relieved Montford Chamney as Registrar of Asiatics and Principal Immigration Officer in the Transvaal.

From being a low-paid correspondent clerk, earning $£ 175$ in 1897, Cousins slowly climbed the hierarchy by hard work and long hours. In 1904 he signalled his progress to his family by sending them a photograph of the colonial office staff with the comment that in 8 years I have worked myself from the back row to the front'. 49 By 1912, he earned $£ 570$ per annum; as father of four children, securing a better income was always in his mind. He supplemented his salary by being an examiner for the history department at the University of Cape of Good Hope and other universities, and by marking junior certificate and matriculation examination papers. Cousins had an annual routine of marking hundreds of papers, which involved long hours. His diary entries reveal the pressures this brought:

I have just got through a very hard day not only of office work but of six hours' correcting of exam papers - the most exhaustive of mental effort I know. Still it has to be done \& so I must keep at it. There is little to tell of my doings. For the present it is examination papers before breakfast - office afterwards - more office \& more papers till exhausted in mind \& body I tumble into bed ...50

\footnotetext{
${ }^{44}$ UCT, Cousins Papers, BC 1154, B2.1, H. Basil Roper to Cousins, 10 March 1905.

45 A.B. Hofmeyr occupied the position between 1904 and 1905 but seemed to have made little impact.

${ }^{46}$ UCT, Cousins Papers, BC1154, A3, letters of appointment.

${ }^{47}$ U. Dhupelia-Mesthrie, 'False Fathers, False Sons: Immigration Officials in Cape Town, Documents and Verifying Minors from India in the First Half of the Twentieth Century', Kronos, 40 (2014), p. 104.

${ }^{48}$ UCT, Cousins Papers, BC 1154, A4.2.1, Diary for 1912, 23 January and 28 November; A4.1.3, Diary for 1913, 3 June.

${ }^{49}$ SOAS, Constance Cousins Papers, Box 2 ms380325/11,Wilfred to Constance, 18 July 1904.

${ }^{50}$ UCT, Cousins Papers, BC 1154, A4.1.2, Diary for 1912, 10 December.
} 
Out at 4.30am for the mail. \& then finished foreigners on Garter Castle. Busy morning \& full day of it. Evening examination papers..$^{1}$

Despite the long hours, Cousins' work ethic is indicated by his diary entry, 'better a strenuous life than a slack one'. ${ }^{2}$ His diaries also reflect personal parsimony, as he sought to manage household expenses.53 At the end of his stint as Principal Immigration Officer at the Cape in 1915, Cousins felt that his work had not been matched by his salary. He had been 'not only an efficient servant ... [but] a very cheap one at that'.54

\section{An Immigration Officer's Work}

Cousins was primarily responsible for setting up the paperwork required for arrivals and departures at the Cape ports, a system that survived for decades. He designed the passenger forms required of disembarking passengers and the permits that Asian residents in the colony were compelled to apply for on leaving the colony, should they wish to return. Separate permits were designed for whites, who could apply for these for purposes of convenience. This paperwork has been considered elsewhere,55 but, as will be shown below, they reflect a belief in differential treatment of different races. Cousins also had an influence in drafting the Union's Immigration Act and the regulations issued. $5^{6}$ The system of permits, renamed certificates of identity, survived Union and became applicable nationally. At the time of Union, Cousins was certainly one of the more powerful of the Union's immigration officers. What is provided here is an attempt to understand the daily routine of the immigration officer at the docks and his interactions with a wide variety of passengers as he made decisions about their fate.

Cape Town was the busiest of the Cape ports. In 1910, 379 steamers bearing passengers called here, in comparison to one at Port Elizabeth and 72 at East London.57 Unlike New York, where passengers disembarked and were shepherded to an offshore shed and later to the Ellis Island station, where they were examined, $5^{8}$ disembarkation in Cape Town took place only after passengers had been processed on board ship. Cousins provides us with a taste of the officer's work:

Immigration officers at a port may not lie abed of mornings like other more fortunate folk. In summer they must rise at $4 \mathrm{a} . \mathrm{m}$, in the winter at 4.30 or $5 \mathrm{a} . \mathrm{m}$, so as to catch the port tug which goes out to meet boats which have anchored in the Bay during the night or are just entering as so many boats are accustomed to do that they may get docked at day break ... The

\footnotetext{
${ }^{51}$ UCT, Cousins Papers, BC 1154, A4.2.1. Diary for 1911, 5 December.

${ }^{52}$ UCT, Cousins Papers, BC 1154, A4.1.2, Diary for 1912, 4 December.

${ }^{53}$ He reluctantly returned a motorcycle that he had been enjoying in 1912. See UCT, Cousins Papers, BC 1154, A4.1.2, Diary for 1912, 28 November, 4 December.

${ }^{54}$ UCT, Cousins Papers, BC1154, B2.2, Cousins to Sir Thomas Watt, 30 June 1916.

55 See Dhupelia-Mesthrie, 'False Fathers and False Sons', pp. 105-7. Without these permits, returning Indians and Chinese were liable to be given the education test.

${ }^{56}$ See UCT, Cousins Papers, BC 1154, A4.1.3, Diary for 1913, 14, 22 February, 3 June.

57 Central Archives Depot, Pretoria (CAD) BNS (Interior), 1/1/595 1/129, Report of the Chief Immigration Officer (Province of the Cape of Good Hope) for the year ending 31 December 1910.

${ }^{58}$ See V. Safford, Immigration Problems: Personal Experiences of an Official (New York, Dodd, Mead and Company, 1925), pp. 1929.
} 
tug becomes a reality, the tossing cannot be denied, and it is with a sigh of relief that the victim of official duty catches hold of the rope ladder just as the tug swings off to have him suspended in space, and eventually finds himself on the deck of a mail steamer or other boat. A cup of coffee does somewhat to put fresh cheer into the little band of officials, and the work begins ... Picture again a Union-Castle Liner, and the smoking room ... an officer in one corner, and a second officer in another. At the door of entrance the portly form of the Detective ....59

Diary entries point to ships not arriving as scheduled, with officers waiting ashore, the pressure of processing 200-300 passengers per ship, the vagaries of Cape Town's weather, weekends sometimes being swallowed up, and late evenings at the harbour.

23 Feb 1909: Up at 4am to meet Norman which after all was late. Cleared at 8.15. Very busy morning.

30 May 1909: Early to dock - but as Intermediate did not come in till afternoon, wasted the whole morning waiting for her. Home late and did not go out. Sorry to have missed S. School.

27 July 1909: To docks as usual - a frightfully rough morning with mail boat anchored 3 miles off B'water. Complexion - green.

3 August 1909: Docks - a lovely moonlight morning, went down on cycle.

9 August 1909: Alan's birthday. Frightful weather \& got very wet going to docks. Dunluce Castle at 12 noon. Lunch on board.

22 August 1909: Wasted whole day over Goth which put in no appearance.

14 December 1909: Early to mail which was late \& not cleared till 7.30. Waited all day for Condrie Castle. Bulawayo in at lunch time ... returned to docks and kept busy.

6 Nov 1911: Intermediate in late evening. Home at 10pm.

4 Dec 1911: Wet morning \& aft. Garter Castle in 8.30 p.m Home at 11.30 pm. Very tired.60

On board ship, the immigration officer examined the completed and signed passenger form, established whether the passenger had $£ 20$ on him/her, and evaluated the basis for entry or denial. Cousins compared his work to that of a judge, with him in the role of 'custodian of the gate'. ${ }^{61}$ He points to the role of 'instinct' in working out the basis 'for all sorts of possible disqualifications which the passenger's papers will not reveal'. Officers were faced with many excuses about the $£ 20$ - such as 'it is in my box ... I can't find it. It must have been stolen'. There were stories of passengers who had set sail with the £2o but spent it en route at Madeira. ${ }^{62}$

\footnotetext{
${ }^{59}$ UCT, Cousins Papers, BC 1154, E5.2, 'The Gates of Africa: Tragedy and Comedy under the Immigration Laws, Paper read to St Andrews Guild', 1917.

${ }^{60}$ UCT, Cousins Papers, BC 1154, A4.2.1, Diary for 1909 and 1911.

${ }^{61}$ UCT, Cousins Papers, BC 1154, E5.1, 'Tragedy and Comedy at the Gates of Africa', lecture to the Jewish Guild in Pretoria, c.1925.

${ }^{62}$ UCT, Cousins Papers, BC 1154, E5.2, 'The Gates of Africa: Tragedy and Comedy under the Immigration Laws, Lecture to St Andrews Guild', 1917.
} 
Passengers who needed more thorough examination than there was time for on board ship were allowed to disembark with a temporary permit while investigations continued at the immigration offices. Once a passenger was pronounced prohibited, more paperwork followed. There could be challenges in the courts in the case of British citizens. Cousins' diary entries reveal the pressure of dealing with prohibits, yet he was unswayed by the legal challenges.

21 April 1909: Very exciting time with threatened Supreme Court action by Alexander for Mrs Freiman.

21 August 1911: Very busy day with prohibits. A rush the whole time. At 5 o'clock practice of Mid. Night's dream \& then to Choral.63

Cousins provided his family with a somewhat embellished account of his encounters with the variety of humankind:

7 November 1912: We had quite an interesting collection of 'cases' on the 'Garter'. There were two undesirable looking Portuguese, a cut-throat Austrian, a weedly-looking Greek, a most degenerate, half-imbecile Russian, a Jewess coming to a husband - who turned out not to be a husband, a Syrian, a helpless English boy without means of support, an English lunatic travelling with a keeper, a young English woman coming to a husband of doubtful existence, and a girl of 19 whose husband left her when they had been married for a month and whom I had to bring up to scratch through the Johannesburg police. Lastly there was an Englishman in advanced consumption with a poor little wife and poor young children. He died on the following morning, and I am sending the family home again.

This morning we had a similar case on the White Star boat 'Rania' [?] - a young girl also in advanced consumption. I have arranged for her to go to a Nursing Home - but it is only a question of days. It is very sad for the mother and sister. ${ }^{64}$

These descriptions point to how Cousins, to a large extent, was a product of his times and reflected settler society's prejudices, which were articulated publicly in many forums. There was a marked difference in his description of the 'helpless English boy' to the Europeans he chose to write about and his soft words for the families of those suffering from tuberculosis. Cousins considered as one of his greatest achievements the deportation of gangsters, criminals and prostitutes. Many of these individuals had been evicted from the Transvaal in the early $1900 \mathbf{s}^{65}$ and headed for Cape Town. Much his work meant ensuring that they were successfully prosecuted, for only then could a deportation be enforced.

Had a consistent photographic record been maintained of the scores, and probably hundreds, who were thus dealt with in a shabby set of offices facing - surely a sublime flight of irony the gates of the Houses of Parliament, there would have been a most remarkable gallery of faces

${ }^{63}$ UCT, Cousins Papers, BC 1154, A4.2.1, Diary for 1909 and 1911.

${ }^{64}$ UCT, Cousins Papers, BC 1154, A4.1.2, Diary for 191

${ }^{65}$ Cammack, The Rand at War, p. 199. She points to more aggressive actions after 1906 
of men and women who had reached into the lowest dregs of degradation. But Cape Town was the cleaner thereafter. 66

Cousins' imagery of cleaning up society would be echoed several decades later by officials of the Group Areas Board bent on declaring group areas, as indicated in the word skoongemaak (cleared) and the removal of black spots (land occupied by blacks within a broader area deemed by the state to be white). ${ }^{67}$

While Cousins saw himself as simply an 'instrument of government policy', ${ }^{68}$ guided by the legislature in his exclusions, he was a bearer of prejudices, some of these widely shared by fellow white South Africans, some influenced by his own upbringing. As a Christian, the idea of Mormon missionaries entering the country was reprehensible to him. Three such persons were prohibited in 1911. Even though they had £20, he found that they had no real means of surviving, since their objective was to proselytise. He offered to educate his superiors in the dangers that Mormons posed to society. ${ }^{69}$ There is much in Cousins' diaries that reflects his prejudices against Jews. In Durban, while relieving Smith of his duties and living in a hotel, Cousins wrote about 'a most objectionable family of Jews', who dominated the shared bathroom. He noted, 'the bath would have wanted a good disinfecting after that crowd - as a matter of sentimental if not actual necessity'.70 When he sought a school for his eldest son, he had much to say about the South African College, which was spoiled by the large numbers of Polish Jews who are sent there ... It is exasperating to find these low-class Jews devouring the land, and making the tone of a big school like that of the South African College lower so much that decent boys cannot be sent there with safety. It is characteristic of these people however in every walk of life - grab then monopolise. ${ }^{71}$

Such private thoughts and encounters are bound to have influenced his work at the port.

He believed that, as one who had physically to encounter the Jews at the port, he was in a better position than the Minister to determine their rights to enter. It was he who saw the Russian and Polish Jews in their hundreds and smelt their 'disgusting odour'. They could not be seen, in his opinion, as 'desirable acquisitions to the country'.72 He wrote in his diary about stopping 'the more miserable specimens' among the Jews.

At the present time I have held up a consumptive Jew - and anyone who knows of their unsanitary domestic habits will not wonder - and a filthy young reptile whose hair is all falling out as the result of some scalp disease. 73

\footnotetext{
${ }^{66}$ UCT, Cousins Papers, BC 1154, E4, Reflections of a Nineteenth Century Immigrant 1896-1950, pp. 14-15.

${ }^{67}$ See [Dhupelia-]Mesthrie, 'Control by Permit' p. 194.

${ }^{68}$ UCT, Cousins Papers, BC 1154, B2.2, Cousins to Sir Thomas Watt, 30 June 1916.

${ }^{69}$ WCA, PIO 17 2148E, Note by Cousins, 9 May 1911.

${ }^{70}$ Cousins Papers, BC 1154, A4.1.2, Diary for 1912, 1 September 1912.

${ }^{71}$ Ibid., 8 November 1912.

72 WCA, PIO 21 2514E, Cousins to Secretary for the Interior, 25 November 1912.

${ }^{73}$ UCT, Cousins Papers, BC 1154, A4.1.3, Diary for 1913, 19 March.
} 
Cousins had little mercy in his judgements of the poor and the illiterate. He was particularly hostile to Madeirans, who were 'scarcely Europeans'.

I may say that in my experience here it has always been a mistake to admit the Madeira natives, as they have invariably drifted into the Town and there collected themselves with the lowest type of coloured people, and followed occupations which frequently brought them into the conflict with the Police.74

Since he was tasked with making a final decision on the writing competencies of many of these individuals, he often used the writing test as an excuse to prevent entry. Cousins barred the landing of two Madeirans, who had work contracts, on the grounds that their writing was not up to standard. When the Portuguese consul questioned his assessment, Cousins stood his ground. He confessed to his superiors: 'I have never hinted to the Portuguese authorities that the question of colour was a consideration in such cases but have merely adhered to my view that the standard of education was insufficient'.75 Jews, Madeirans, Italians, Greeks and other such nationalities became the target of the writing test originally included to keep out the East.

While there has been no study of how the writing test was administered in South Africa, some preliminary comments are offered here. ${ }^{6}$ The test involved writing a few sentences on the back of the passenger form as an application to enter the country. Individuals could choose what to write. An American Jew, seeking entry at Cape Town, was denied landing in 1912 after he wrote:

I was citizen of America ... I have not been in South Africa befor

I am suffishiently Edzecated to meet the rekwasements of the Emigraiton Act. I am proseedig Janseville for the purpose of transaction the bisnes of a storekeeper.77

Harry Frangopaulos, described as a Greek general dealer arriving from Madagascar, was also turned down after he wrote 'I am a taket in Englis'. Cousins noted on his passenger form 'undesirable in appearance', with only £10.14s on him. The writing test was just one measure of evaluation, with other criteria affecting its outcome.78

In 1911, when the 'coloured American 'David Hawkins sought entry with his wife and child, hoping to find work as a farm labourer, Cousins, after examining his writing, deemed him inadmissible. His writing sample (see Figure 1) indicates that, while he could form the alphabet, his spelling and grammar were, in fact, far from satisfactory. Cousins ruled: '[h]is writing is hopeless, and I take it that the minister would not favour the introduction of a coloured

\footnotetext{
${ }^{74}$ WCA, PIO 15 1948E, Cousins to the CIO Pretoria, 6 October 1910.

${ }^{75}$ Ibid.

${ }^{76} \mathrm{I}$ am in the process of writing up such an article. For Australia's test, see J.C. Martens, 'Pioneering the Dictation Test?: The Creation and Administration of Western Australia's Immigration Restriction Act, 1897-1901', Studies in Western Australian History, 28 (2014), pp. 47-68. This involved a dictation from an English text chosen by an officer, and he could also choose from any European language with which the immigrant was not familiar.

77 WCA, PIO 21 2495E, File of Jacob Frankel.

${ }^{78}$ WCA, PIO 17 2151E, File of Harry A. Frangopoulos.
} 
person of this type'.79 The writing test was also linked to the immigration officer's assessment of the mental capacity of potential immigrants, and could be used to keep out the 'mentally weak'. ${ }^{80}$ It was left to Cousins, who bore the power of the Colonial Secretary (later Minister of the Interior) in this matter, to decide what a suitable standard of writing was. The record reveals that decisions could be subjective and even adjustable. Appeals from consular officials sometimes produced a reversal of judgement. An Italian fisherman arriving in 1910 managed to write in Italian 'io nato in italia' (I was born in Italy) and a further text in Italian, which, when translated, read 'I have just arrived from Europe.

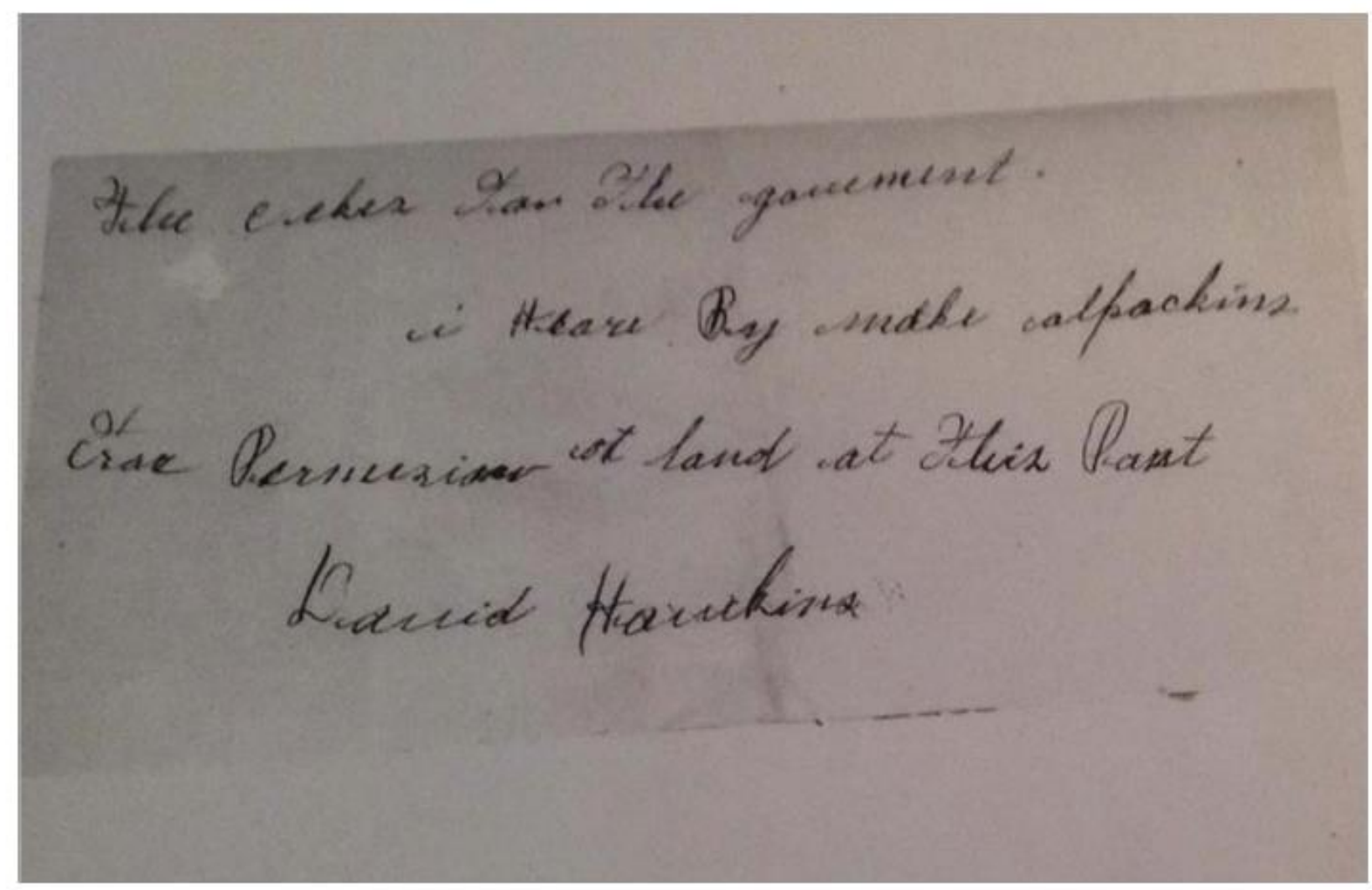

Figure 1. Writing test (Source: Western Cape Archives and Record Services, PIO, 16, 2058, file of David Hawkins).

I am a fisherman and wish to obtain permission to remain in this colony of possible. I am a native of Italy'. He was prohibited. After appeals by the Italian consulate, whose opinion was that the man had 'mediocre but understandable' writing and was guaranteed employment by a fellow Italian, Cousins yielded. Yet he indicated to the Colonial Under-Secretary, 'he certainly cannot write grammatically and in the past I have maintained for persons of this type a comparatively severe standard of education to make it difficult for Italians of his class to enter the country'. ${ }^{81}$ In another case, the Italian consulate was not successful. While Cousins administered a second writing test, he upheld the original verdict, noting: ' $\mathrm{t}]$ his Italian was a man of great stature and strength, of the roughest and most dangerous Italian type, he

\footnotetext{
${ }^{79}$ WCA, PIO 16 2058E, File of David Hawkins.

${ }^{80}$ WCA, PIO 15 1949E, File of Motel Leib Sneig.

${ }^{81}$ WCA, PIO 12 1658E, File of Petracco Mauro.
} 
carried a revolver; stated he was a Californian miner, and both in appearance, style and type seemed unquestionably undesirable'. 82

A young Jewish man was prohibited because of illiteracy (he was, Cousins noted, unable even to sign his name). A month later, he returned to Cape Town, after spending time in London learning how to sign by tracing his signature. This time he gained entry, the reason being the enormous pressure that Jewish groups placed on the Colonial Secretary and Cousins himself. Cousins now noted: '[a]s he comes of a very respectable family I accepted the handwriting'. ${ }^{8}$ Two Russian Jews who arrived at Port Elizabeth in 1913 were prohibited on the grounds of their writing, but they were also noted as being 'dirty'. They proceeded to Delagoa Bay, practised their writing, and returned to Cape Town. In the interim, there had been much pressure on the Minister of the Interior from the Jewish Board of Deputies. This time Cousins noted: '[t]hey have returned from Delagoa Bay - transformed in costume - and redolent of soap and water. Had they appeared originally in this form ... one would have overlooked other disqualifications'.

Though he still maintained that their writing was 'of the lowest standard', they were permitted entry. 84 The administration of the writing test reveals that race, appearance, class, and pressure groups played a role in who passed the test and who did not. A few Indians, it may be mentioned, for all the prejudices against them, managed to pass the writing test and were allowed entry. After 1913, though, there was no such possibility. 85

While Cousins revealed many prejudices, it is in his attitude to young women passengers that we see a paternalistic side emerging. He assumed the role of protector of young women, saving them from preying men. He recounted one case where a young woman had arrived in Cape Town to marry a local resident, but officials had already received intimation that the man was married. The couple were interviewed at the immigration offices, where the man confessed. Cousins noted, 'it was a bitter experience but it saved the girl'. She was returned to England at the expense of the deceiving male. ${ }^{86}$

Cousins advised his officers to take extra care when assessing young women for landing. He used as an example a 17-year-old German who had arrived with barely $£_{7}$, but who could write. She was fetched from the harbour by an uncle. It later turned out that this man was not, in fact, an uncle. The girl was taken to an 'aunt' who lived in Cape Town, only to find that her place in the household was as 'a scrubbing girl'. Using the difficulties of this case, which came to his attention because the girl was subsequently destitute, Cousins warned his officers to take heed of his 'desire repeated again and again in the past that young girls coming to the care of friends or relatives other than their parents should be most carefully questioned and the most strict guarantees obtained for their care and maintenance'. ${ }^{87}$ Not

\footnotetext{
82 WCA, PIO 15 1911E, File of John Ossalini.

${ }^{83}$ WCA, PIO 8 1254E, File of Jacob Freedman.

${ }^{84}$ WCA, PIO 23 2682E, File of Benjamin and Wigdor Jalwesky.

${ }^{85}$ One of these was Sadashive Sathe. See WCA, IRC 1/1/255 5761a.

${ }^{86}$ UCT, Cousins Papers, BC 1154, E5.1 'Tragedy and Comedy at the Gates of Africa', lecture to the Jewish Guild, c.1925.

${ }^{87}$ WCA, PIO 24 2656E, File of Hilda Nitzsche, Note by Cousins, 24 October 1913.
} 
far from his mind was the trafficking of young girls ('the White Slave traffic') ${ }^{88}$ and the possibility that destitute girls would turn to prostitution.

Cousins also made decisions about who should be repatriated. Indians could take advantage of the repatriation scheme of free travel and bonuses. A study of Cousins' work shows how repatriation affected others as well. He often had to make decisions about people who had lived in the country for a while but whose circumstances had changed due to old age, mental illness, infirmity, alcoholism, and who would clearly become a burden on the state. In such cases, Cousins took care to investigate circumstances, and once it was ascertained they had family in their country of origin, they could be repatriated at state cost. ${ }^{89}$ Like the writing test, repatriation has to be broadened from its links to those from India to a consideration of other unwanted individuals, who were sent back to England and Europe and elsewhere in the world. The 'decayed gentlewoman' from England who was, after many years in Cape Town, too old to be employed, 90 the Italian who was insane, 91 the domestic servant who was undesirable because of 'her inability to control her temper apparently as the result of her habit of drug- taking or smoking', ${ }^{92}$ the paralysed Danish man,93 the alcoholic Englishman:94 all have a place in narratives of repatriation.

\section{The Immigration Officer and the Oriental}

When Cousins was called upon in 1925 to give a talk on his work as an immigration officer, he chose to dwell on humorous and entertaining episodes, shipwrecks, and quirky passengers. He did not speak about his work with Asian passengers, explaining that it 'would take up a whole evening', but he did give a hint as to 'the tricks and wiles, the fraud and guile [lies crossed out], the baksheesh [bribery crossed out] and the persistence of the orientals who sought admission into South Africa'. He outlined the origins of exclusionary legislation, pointing to Natal's attempts to keep out the 'Bombay Mohammedans' in 1897 and its impact on Cape Town, where 'boat-load after boat-load crowded with Indians came down from the coast past Durban where they were no longer allowed to land and were turned out in bulk on to the quays at Cape Town'. This led to the law that he had been appointed to administer. Cousins expressed the opinion that '[i]t was one thing to deal with white people, but quite another to deal with orientals'.95 He was referring here mainly to Indians, for he noted elsewhere, '[i]t is very seldom that Chinamen play tricks they usually leave this to the Indians'. ${ }^{6}$ This probably had more to do with the numbers of Indians that the Immigration Department had to deal with, for the Chinese in the colony numbered under 1,000 in 1910, while the Indian population was more than six times as great.97

\footnotetext{
${ }^{88}$ UCT, Cousins Papers, BC 1154, A4.1.3, Diary for 1913, 25 June 1913.

${ }^{89}$ See, for instance, WCA, PIO 20 2344E, case of John Crawley; WCA, PIO 18 2235E, case of Mrs Ashford and children.

${ }^{90}$ UCT, Cousins Papers, BC 1154, E5.1, 'Tragedy and Comedy at the Gates of Africa', lecture to the Jewish Guild in Pretoria , c.1925.

${ }^{91}$ WCA, PIO 24 2670E, File of Louis Phillis.

92 WCA, PIO 24 2655E.

${ }^{93}$ WCA, PIO 23 2621E.

94 WCA, PIO 20 2344E.

${ }^{95}$ UCT, Cousins Papers, BC 1154, E5.1, 'Tragedy and Comedy at the Gates of Africa', lecture to the Jewish Guild in Pretoria , c.1925. His published memoir also devotes little attention to this side of his work. See UCT, Cousins Papers, BC 1154, E4, Reflections of a Nineteenth Century Immigrant 1896-1950.

${ }^{96}$ UCT, Cousins Papers, BC 1154, A4.1.2, Diary for 1912, entry 8 December.

${ }^{97}$ There were 6,600 Indians in the Cape in 1911, and 833 Chinese in 1910. See Bhana and Brain, Setting Down Roots, p. 194, and CAD, BNS 1/1/595 1/129, Report of the Chief Immigration Officer for the Cape Colony for the Year 1910.
} 
Apart from the 'unscrupulous cunning' of the Indian and their 'appalling lying', which he noted for his family's benefit, 98 Cousins found aspects of their way of life troubling. As an English immigrant, he had made the transition to Cape settler. He expressed what Dubow has called a 'colonial nationalism' - a belief that the material growth and welfare of the colony had to be prioritised, that a commitment to the colony had to be made, though this did not exclude an affinity for the home country. 99 Indians challenged this in their persistence in leaving wives and children in India instead of creating a settled family life in the Cape, and they exported their earnings back to India, in turn contributing little to Cape society. Reflecting his Christian beliefs of what was 'civilised' behaviour, Cousins found their polygamous and also child marriages unacceptable. ${ }^{100}$ Cousins was particularly hostile to the low-class Bombay country- folk Mohammedans'.101 Muslims from present-day Maharashtra in fact made up the majority of Indians in Cape Town. Cousins implied that Indian bodies were like a disease in Cape society:

To-day we have had another boat with Indians, \& Parliament St. has been so infested with them all day that our work must be exceedingly well advertised to members of parliament. I was thoroughly tired out by 6 o'clock. It is a dreadful exertion trying to keep level with the torturous ways of the wily oriental. ${ }^{102}$

Debates about immigration, Perbedy has argued, were often 'shot through with metaphors of disease, degeneration, invasion and contamination', ${ }^{103}$ and it is thus not unexpected that such imagery surfaces in the writings of the Chief Immigration Officer.

It does not surprise the historian, further, that Cousins chose not to speak or write more extensively about Indians in his public lectures or memoirs. Although a minority constituting not even half of one per cent of the population of the Cape Colony, 104 immigration issues affecting Indians in the Cape featured in two select committees, a commission of enquiry in 1914 and another in 1915, and a public services commission in 1916. All this placed Cousins' administration under scrutiny. Cousins survived an assassination attempt by an Indian with an 18-inch butcher's knife in 1913, and lived to hear a devastating critique of his administration by a Supreme Court judge three years later. Fraud, bribery and corruption all came to the fore. Although Cousins was already in his new post in Pretoria, the judgement stung, and he felt that 'the career of a lifetime' had been damaged.105

\footnotetext{
${ }^{98}$ See UCT, Cousins Papers, BC 1154, A4.1.2, Diary for 1912, 20 May; A4.1.3, Diary for 1913, 25 April.

${ }^{99}$ Dubow is quoted and explained in Duff, 'Saving the Child', p. 234.

${ }^{100}$ See U. Dhupelia-Mesthrie, 'Split-Households: Indian Wives, Cape Town Husbands and Immigration Laws, 1900s to 1940s', South African Historical Journal, 66, 4 (2014), pp. 642, 647, and U. Dhupelia-Mesthrie, 'India-South Africa Mobilities in the First Half of the Twentieth Century: Minors, Immigration Encounters in Cape Town and Becoming South African', in M. Rodet and E. Razy (eds), African Children's Migrations; Key Issues and New Perspectives (London, James Currey, 2016 forthcoming).

${ }^{101}$ UCT, Cousins Papers, BC 1154 B1.3, Family Letters, 10 December 1914.

102 UCT, Cousins Papers, BC 1154, A4.1.3, Diary for 1913, 24 February.

103 Perbedy, Selecting Immigrants, pp. 50-51.

${ }^{104}$ In 1904, they were 0.35 per cent of the total population. See G19-1905, Results of a Census of the Colony of the Cape of Good Hope as on the Night of Sunday the 17th April 1904, pp. xxi, 68-9.

${ }^{105}$ UCT, Cousins Papers, BC 1154, B2.2, Cousins to Thomas Watt, 30 June 1916.
} 
The controls over the movement of Indians between India and Cape Town, and their woes under Cousins' bureaucracy and the above events, have been dealt with in greater detail elsewhere, ${ }^{106}$ but a few significant points will be highlighted. Due to the writing test and the requirement of £20, there were few new Indians arriving in the colony. In 1910, for instance, of 33,272 passengers arriving at the Cape ports, 10,348 were new arrivals, and, of these, only 58 males and 13 females were British Asians, with 61 coming from Indian ports. ${ }^{107} \mathrm{New}$ arrivals from India could only be minors and wives but, as seen below, the work involved in processing these individuals was out of proportion to the numbers.

Permit work ${ }^{108}$ was the central way in which immigration officials engaged with Indians. To enable Indians already resident in the colony to travel to India and return, a compulsory permit system was instituted. For whites travelling outside the colony, this was not mandatory, but they could apply for convenience of entry. Cousins' central belief was explicitly stated:

It is not possible to deal with the Asiatic as with the European; the whole nature of the man is oriental, his habits are different from those of the European, and legislation that would apply easily to the European is not applicable to the Asiatic; and that is one of our difficulties with the Asiatics and Europeans - they are both dealt with under the same law, and so a great deal of discrimination is necessary in administering the law. ${ }^{109}$

In keeping with this belief, 'Asiatic permits' were different from those issued to whites, in that photographs and thumbprints were not compulsory for the latter. It was these two aspects of work - admitting Indian minors and administering the permit system - that gave Cousins and his staff the greatest amount of work.

Given that Indians could bring in only their children and not brothers, cousins, village members, and shop assistants, many resorted to subterfuge and passed off young boys as sons. The lack of birth certificates from India added to their ability to fictionalise relationships and also to falsify documents. So Indians did in fact lie about these things, and the task of the immigration officer was to unravel the lies and get to the truth. ${ }^{110}$ Cousins informed his family of his fellow immigration officer Davison's view that 'their ways make him "dizzy" - which puts the thing expressively'. ${ }^{111}$ When he was in Durban for his six-month stint in 1912, he found similar deceptions. ${ }^{112}$ His diary entries in Cape Town also point to his frustration:

\footnotetext{
${ }^{106}$ See Dhupelia-Mesthrie, 'False Fathers, False Sons'; 'The Passenger Indian as Worker'; 'Cat and Mouse Games: The State, Indians in the Cape and the Permit System, 1900s-1920s', in I. About, J. Brown, G. Lonergan (eds), Identification and Registration in Transnational Perspective: People, Places and Practices (New York and London, Palgrave Macmillan, 2013), pp. 185-202. 'SplitHouseholds'; 'Engaging with Immigration Laws and the Bureaucracy: Indian Immigration Agents, Interpreters and Reformers in Cape Town, 1902 to 1916', unpublished paper presented to International Conference on Poetics of Law, Politics of Self, Plymouth University, UK, 5 September 2013.

${ }^{107}$ CAD, BNS, 1/1/595, 1/129, Report of the Chief Immigration Officer for the year 1910.

${ }^{108}$ See Dhupelia-Mesthrie, 'The Passenger Indian as Worker' and 'Cat and Mouse Games'.

${ }^{109}$ SC 16-1908, Report of the Select Committee on Asiatic Grievances (Cape Town, Government Printers, 1908 ), p. 111.

110 This is more fully dealt with by me in 'False Fathers, False Sons'.

${ }^{111}$ UCT, Cousins Papers, BC 1154, B1.3, Family letters, 20 February.1915.

${ }^{112}$ UCT, Cousins Papers, BC 1154, A4.1.2, Diary for 1912, 7 August.
} 
1. February 1912: Very busy day with Indian sons - working all lunch hour \& home $7.15 \mathrm{pm}$. Exhausting sort of exercise. Hurried tea \& then off to quarterly teachers' meeting at Lancaster House.

2. February 1912: Very busy day statements from Indians as to their 'minor sons'. Exposed 4 pretty bad cases \& hope to be rid of them. ${ }^{113}$

Cases could unravel several years after an entry, when inconsistences in biographical details exposed the immigrant. Between 1907 and 1909, Indians constituted more than one-third of all deportees: 47 in 1907, 34 in 1908 and 46 in 1909. ${ }^{114}$

Cousins deplored the propensity of Indians for litigation and spent an inordinate amount of time before making a decision. His diaries reveal long hours at the detention depot, leading to curtailment of weekend recreational activities and Sunday School.

25 February 1913: What a strenuous day it has been - finishing off a number of Indian cases and dealing firmly with lawyers interesting themselves in the cases. I wonder if there is any Government Officer who has as much to do with attorneys as I have. Experience has made me a pretty fair match for them, but one does get tired of being for ever on the defence.

4 March 1913: The only way to circumvent these people has been to be more careful in going into their cases. ${ }^{115}$

Cousins displayed considerable joy when court decisions went his way. On one particular day, when he was particularly victorious, he encountered a different sort of undesirable in his domestic space: a cat and five kittens. 'The kittens were dangerous things and I had to noose them one by one. There were six of the cat tribe less today'. ${ }^{116}$ Another day went as follows: '[b]usy day still at work on Indians. Spent early part of evening beginning a bureau. Then with Wyn to teachers meeting at Lancaster House'. ${ }^{117}$ Cousins was a keen woodwork enthusiast, and produced many a household item of furniture amid all the work that the port brought.

It was Cousins' faith in a fellow immigration officer, William van Rheede van Outdshoorn, and his trust in two Indian immigration agents (one Hindu and one Muslim), whom the department also employed at times to interpret for them, that was the undoing of his administration. ${ }^{118}$ Cousins relied on van Oudtshoorn to oversee the permit applications as well as to go down to the docks to meet the ships carrying Indians. A market developed in permit forms, and

\footnotetext{
113 UCT, Cousins Papers, BC 1154, A4.1.2, Diary for 1912.

114 CAD, BNS 1/1/595, 1/129, Report of the Chief Immigration Officer for 1910. Statistics of deportees could vary - in 1910, for instance, there were as many British as Indians deported and even more from Russia, but each year Indians constituted a significant group.

${ }^{115}$ UCT, Cousins Papers, BC 1154, A4.1.3, Diary for 1913.

116 Ibid., 7 February.

${ }^{117}$ UCT, Cousins Papers, BC 1154, A4.2.1, Diary for 1912, 20 May.

118 This has been dealt with by me in 'Engaging with the Bureaucracy' and 'Cat and Mouse Games', and by A. MacDonald, 'The Identity Thieves of the Indian Ocean: Forgery, Fraud and the Origins of South African Immigration Control, 1890s-1920s', in K. Breckenridge and S. Szreter (eds), Registration and Recognition: Documenting the Person in World History (Oxford, Oxford University Press, 2012), pp. 253-76.
} 
these were issued to Indians who had never been in the Cape before but whose biographical details had been invented by the agents with the colluding immigration officer. While Cousins supplemented his income by marking exam papers, the younger van Oudtshoorn, who also had four young children to support, found it profitable to come to the aid of Indians desperate to enter Cape Town. Such individuals who entered with false papers remained susceptible to bribery by agents and other Indians. It was one such entrant, who felt that he was fleeced for his entry, who attacked Cousins with a knife, wrongly believing him to be responsible for his woes.

The fraud in the department began to be unveiled by Cousins only in 1914, when van Oudtshoorn was transferred to the censor's office during the war. Cousins began studying permit applications, and found much to implicate his trusted friend. The enquiry of 1915 brought forth Indian witnesses who implicated van Oudtshoorn and the agents. The report criticised Cousins for lack of proper oversight, a point also raised by the judge when reading out the verdict in van Oudtshoorn's subsequent prosecution case and supported by the later public services commission. Ten years of Cousins' administration came crashing down, and it was those from India who played a role in this. While Cousins was deeply wounded, this was not the end of his career in the civil service. He went on, after a short stint as Registrar of Asiatics in the Transvaal, to be chairman of the Statistical Council, then Director of Census, and ended his career in 1931 as Secretary for Labour, a post he had held for eight years.

\section{Conclusion}

This study of the work of an immigration officer provides insight into an aspect of the South African civil service that has not been given sufficient attention in South African historiography. Immigration histories have focused on policy, and often remain narrowly focused on the country of origin, and more especially the ethnicity, of immigrants. This article broadens the study of immigration by taking the port of arrival and the officer as the starting point. Cousins, undoubtedly a hard-working civil servant, saw himself as one who could clean up South African society and shape it (as did later apartheid officials). This article argues that, while the officer may have been carrying out the law of the land, there was personal discretion. Class, race, religion, English settler masculinity and ideas of respectability all played a role in way the immigration officer operated at the port and made decisions. Cousins' views about the poor, the mentally ill, criminals, Jews and Indians were, of course, sanctioned by legislators in their intent and definition of who was undesirable, and his prejudices were a reflection of the society and times in which he found himself. In turn, subjectivities and a personal determination to implement the law without softness played a role at the port. Cousins recognised that an officer such as himself was seen by those who bore the brunt of his work as a man of harshness. He momentarily wondered whether he could have made his own life easier by taking a 'more lenient view of my responsibilities' and becoming 'a man of heart'. ${ }^{119}$ In his opinion, he was doing what he was appointed to do, and he executed his duties without regard for popularity. He admitted later that many mistakes of judgement could have been made, since the immigration officer was

${ }^{119}$ UCT, Cousins Papers, BC 1154, BC 1154 A4.1.2, Diary for 1912, 28 November; also B1.3, Family letters, 20 May 1916. 
'humanly fallible'. ${ }^{120}$ Yet his official papers point to the firmness and conviction with which he made decisions.

Connectivity has been a major theme in Indian Ocean studies, and Africa has been given a significant place in recent Indian Ocean history, thus addressing a lacuna in older Indian Ocean studies. ${ }^{121}$ This article points to the connectedness between the southern African ports, for action taken at one port had implications for other ports, and systemic connections emerge. ${ }^{122}$ This article seeks, though (at the risk of swimming against the current), to move beyond the Indian Ocean connectivity theme and argue for a conceptualisation of the port in terms of its attraction for people from all parts of the world. Looking only to the Indian Ocean or only to the Atlantic Ocean for passenger arrivals and steamships (as South African historiography has been wont to do) can limit an understanding of the port, its attractions, and, more specifically, the labour of port officers. The article seeks gently to delink the hard fastness with which the writing test and repatriation has been associated with Indian Ocean mobilities. They have a significance, it argues, beyond their association with India.

It has taken some time for Cape Town to be seen by historians as a significant Indian Ocean port. ${ }^{123}$ Yet how did Cape Town settler society view itself? The article points to Cape Town's considerable unease at the growing links between India and the city through arrivals of Indian passengers. There was a determination to keep the East at bay and to establish a disconnect, so that Cape Town did not become a Bombay, as had been Durban's fate. A child of the Indian Ocean himself, Cousins reflected little love of what this sea traffic brought to his port. He guarded the gates equally against those deemed undesirable from the Atlantic Ocean. Sea crossings from India to Cape Town none the less shaped his bureaucracy and played a role in the career of the hard-working civil servant, Bible-class teacher, choirmaster and organist, history examiner, woodwork enthusiast and cat killer - Wilfred Cousins.

\footnotetext{
${ }^{120}$ UCT, Cousins Papers, BC 1154, E5.1, 'Tragedy and Comedy'.

${ }^{121}$ More recently, scholars have sought to refine the idea of connectedness. See F. Becker and J. Cabrita, 'Introduction: Performing Citizenship and Enacting Exclusion on Africa's Indian Ocean Littoral', Journal of African History, 55, 2 (2014), pp. 161-71.

${ }^{122}$ Andrew MacDonald has also shown that with the tightening up on entry at the South African ports after Union, Delagoa Bay became the new hotspot for illegal entry into the country. See 'Forging the Frontiers: Travellers and Documents on the South AfricaMozambique Border, 1890s-1940s', Kronos, 40, 2014, pp. 154-77.

${ }^{123}$ See Nigel Worden's article in this issue.
} 